\title{
0 fim do passe e as transferências de jogadores brasileiros em uma época de globalização
}

FRANCISGO KAUIER FREIRE RODRIEUES"

\section{Resumo}

O artigo aborda as recentes transformações na legislação futebolística brasileira e seus impactos no mercado de trabalho. Analisa a influência do fim do passe nas transferências (internas e externas) de jogadores de futebol no Brasil. Trata-se de uma investigação empírica, o fim do passe e a exportação de jogadores brasileiros. Utilizamos técnicas de pesquisa quantitativas e qualitativas (questionários e entrevistas). Aplicamos 97 questionários com atletas de 12 clubes do campeonato brasileiro de futebol das Séries A, B e C. A pesquisa indica que o fim do passe criou novas condições para as transferências internas e externas de jogadores brasileiros. Houve crescimento significativo das transferências internacionais de jogadores depois do fim do passe, acentuando a exportação de atletas brasileiros. Além da globalização, as razões desse crescimento devem-se ao fato de que a Lei Pelé facilitou as transferências ao decretar o fim do passe, estabelecer a liberdade de trabalho e flexibilizar os contratos.

Palavras-chave: Futebol. Globalização. Transferências de jogadores. Fim do passe. Exportação.

\footnotetext{
* Professor Efetivo Adjunto I do Departamento de Sociologia e Ciência Política e Professor Colaborador do Programa de Pós-Graduação em Estudos de Cultura Contemporânea na Universidade Federal de Mato Grosso (UFMT).
} 


\section{Introdução}

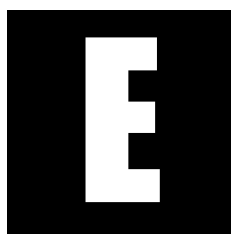

ste artigo analisa a influência do fim do passe nas transferências (internas e externas) de jogadores de futebol no Brasil. Trata-se de uma investigação sobre as relações entre as mudanças na legislação futebolística brasileira que entrou em vigor com a Lei Pelé (no 9.615/98), as transferências internas de jogadores e a exportação de atletas brasileiros.

O referencial teórico utilizado é composto de estudiosos da Sociologia, da Sociologia do esporte, da Antropologia e do Direito esportivo, destacando-se os seguintes autores: Bourdieu (1988), Helal (1997), Giulianotti (2002), Proni (2000), Damo (2005), Melo Filho (2004, 2001), Alcântara (2006), DaMatta (1982 e 1994), Maciel (2003), Napier (2003), Carravetta (2006, 2001), Afif (2006), Leoncini (2005) e Gurgel (2006).

O texto é dividido em duas grandes partes. A primeira apresenta uma caracterização geral dos atletas entrevistados (97 no total), destacando a origem dos jogadores por regiões e Estados, número de atletas entrevistados por clube, idade, idade da profissionalização, grau de instrução, nível de renda, índice de sindicalização e as formas de ingresso nos clubes.

A segunda parte aborda a relação entre o processo de globalização e as transferências de jogadores brasileiros no período pós-lei Pelé (depois da entrada em vigor do fim do passe, a partir de 2001). Apresenta o percentual de jogadores brasileiros que já atuaram no futebol do exterior. Analisa a percepção dos jogadores brasileiros sobre as transferências e a exportação de atletas pós-fim do passe. 
Caracterização socioeconômica dos jogadores entrevistados

Origem dos jogadores entrevistados

Apresentam-se, a partir de agora, dados de uma pesquisa realizada em 2005/2006 com atletas das três divisões do futebol brasileiro (Séries A, B e C).

\section{Gráfico 1 - Origem dos atletas entrevistados por região}

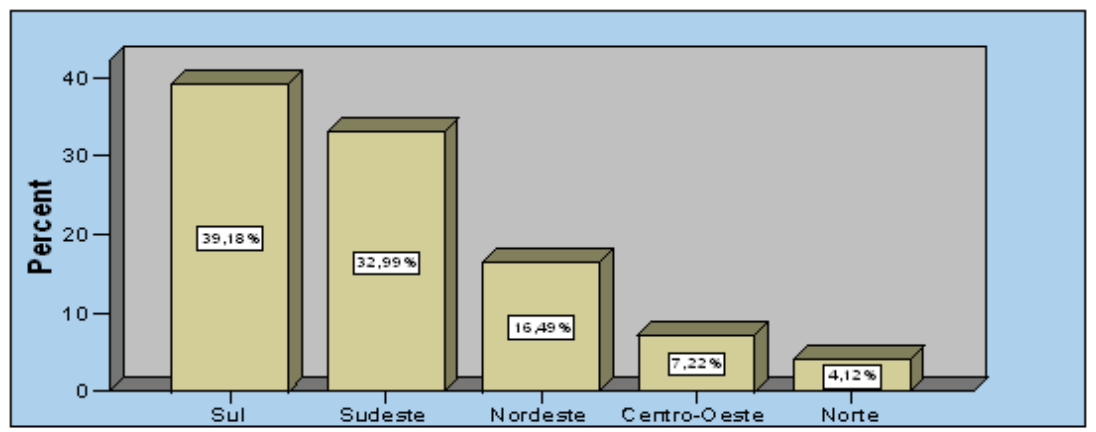

Fonte: Pesquisa de Campo 2005/2006

O Gráfico 1 mostra a distribuição dos atletas entrevistados por região de origem. Verifica-se que a maioria dos atletas pertence à região Sul (39,18\%). Tem-se também 32,99\% de atletas do Sudeste, 16,49\% do Nordeste, $7,22 \%$ do Centro-Oeste e 4,12\% da região Norte.

No Gráfico 2, observa-se a distribuição dos atletas entrevistados por Estado de origem. Predominam atletas de São Paulo (22,68\%) e Rio Grande do Sul (22,68\%), seguidos por atletas oriundos do Paraná (11,34\%). Cabe recordar que a seleção dos times incluídos na amostra, pode ter tido forte influência nessas participações, visto que 5 clubes pesquisados são do Rio Grande do Sul e 1 do Paraná. 


\section{Gráfico 2 - Distribuição dos atletas entrevistados por estado de origem}

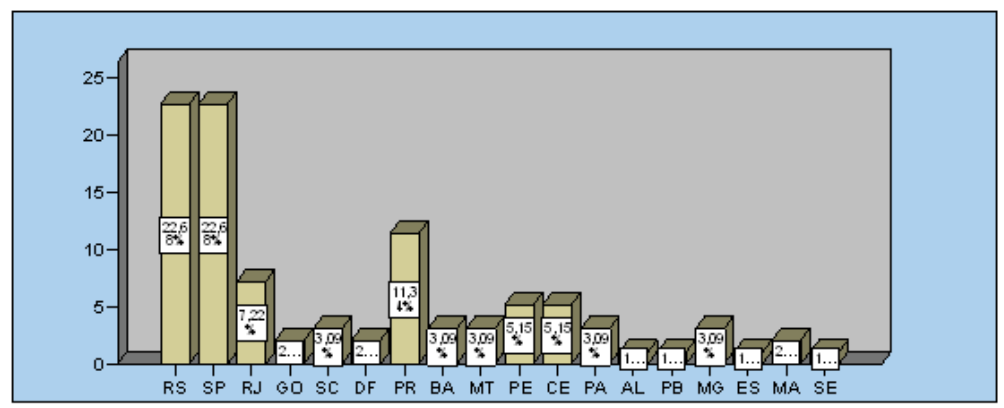

Fonte: Pesquisa de Campo 2005/2006

Número de jogadores entrevistados por times e aprendizagem de futebol

Os dados relativos ao número de atletas entrevistados por times são apresentados no Gráfico 3. O Caxias - RS foi o clube que mais teve jogadores entrevistados (13), seguido de Grêmio - RS e do Fluminense - RJ (com 11 atletas cada). Paysandu-PA (04), Vasco da Gama - RJ (04) e Curitiba - PR (07) foram os clubes que cederam menos atletas para entrevistas, alegando indisponibilidade de tempo dos jogadores.

Gráfico 3 - Número de atletas entrevistados por times

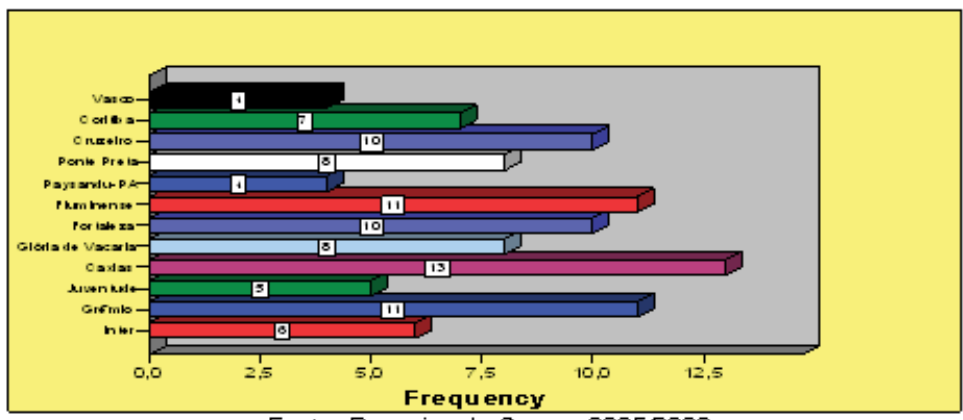

Fonte: Pesquisa de Campo 2005/2006 
A maioria dos atletas entrevistados aprendeu a jogar futebol nas escolinhas (39,18\%). Este dado é revelador de uma realidade na qual o futebol é uma modalidade sustentada pela ciência. Aprende-se a praticar o futebol nos espaços especializados (escolas) (DAMO, 2005; CARRAVETTA, 2001). Por outro lado, um número significativo de jogadores acredita que não se aprende a jogar futebol, mas se nasce com o dom (31,96\%), algo natural que necessita apenas ser despertado (Gráfico 4). No entanto, admite-se que nem todos os indivíduos possuem as características/ elementos que os possibilitam a se tornarem atletas profissionais do futebol. Mas, para despertar o dom, é necessário um trabalho sistemático de treinamento, algo que se recebe nas escolinhas de futebol (DAMO, 2005; RODRIGUES, 2003; CARRAVETTA, 2001; TOLEDO, 2002).

\section{Gráfico 4 - Aprendizagem de futebol}

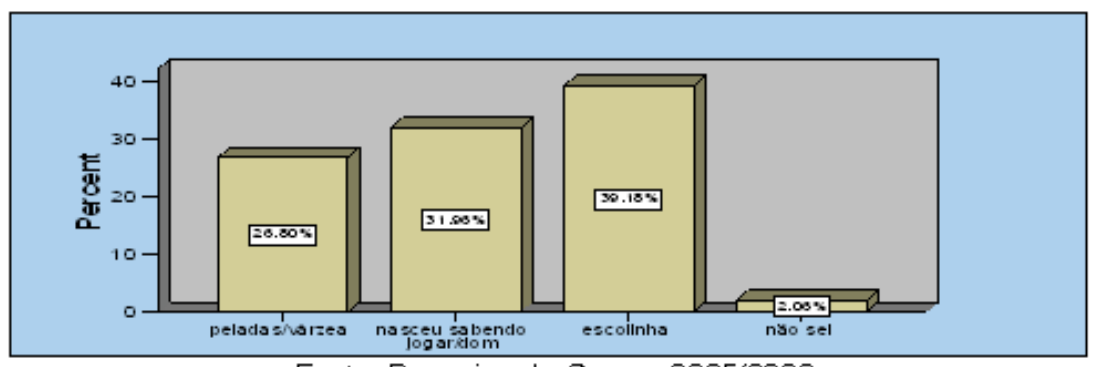

Fonte: Pesquisa de Campo 2005/2006

As 'peladas' formaram muitos jogadores no futebol brasileiro, especialmente antes do advento das escolinhas de futebol. Alguns estudiosos do nosso futebol (DAMATTA, 1994, 1982; TOLEDO, 2002; RODRIGUES FILHO, 2003) defendem que as 'peladas' influenciaram a constituição do estilo brasileiro de jogar futebol, caracterizado pela individualidade, arte 
e malandragem. Cerca de $26,80 \%$ dos jogadores afirmaram que aprenderam a jogar futebol nas peladas.

Em "A Formação do Jogador de Futebol no Sport Club Internacional (1997-2002), Rodrigues"1 (2003, p. 137) constatou que 46\% dos jogadores do SC Internacional de Porto Alegre - RS aprenderam a jogar nas 'peladas' (nos campos de várzeas), 27\% dos atletas aprenderam a jogar futebol nas escolinhas, o mesmo percentual dos que responderam que já nasceram com o "dom" para jogar futebol.

Faixa etária dos jogadores e idade da profissionalização

Os dados do Gráfico 5 referem-se à idade dos jogadores pesquisados. Percebe-se que a menor idade é 17 anos e a maior, 36 anos. A idade de maior freqüência é a de 23 anos, cabendo deixar claro que a média de idade dos atletas brasileiros é de 23 anos, média que se considera relativamente baixa (mas a média de idade dos atletas na França é de 19 anos (Le Monde, 07/12/2001).

\section{Gráfico 5 - Idade dos atletas entrevistados}

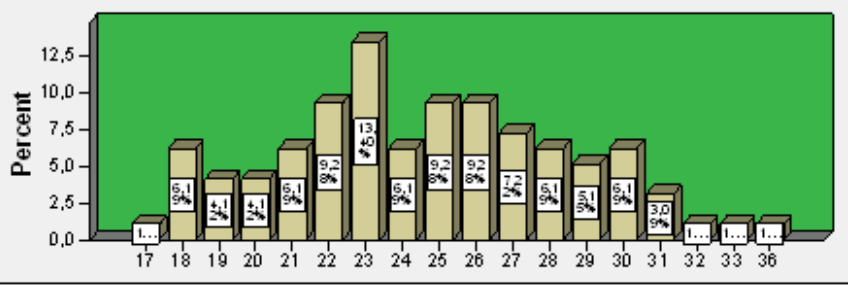

F onte: Pesquisa de Campo 2005/2006

1 Ver especialmente os capítulos 4 e 5. 
Conforme o Gráfico 6, 44,33\% dos entrevistados na pesquisa, entre 2005 e 2006 se encontravam na faixa etária de 20 a 25 anos. Trata-se de um padrão baixo de idade e adequado ao futebol moderno, que exige atletas novos e fortes, pois o mesmo se encontra em uma fase do futebol na qual se valoriza demasiadamente a força e o preparo físico (CARRAVETTA, 2006; DAMO, 2005; RODRIGUES, 2003).

\section{Gráfico 6 - Faixa etária dos jogadores pesquisados}

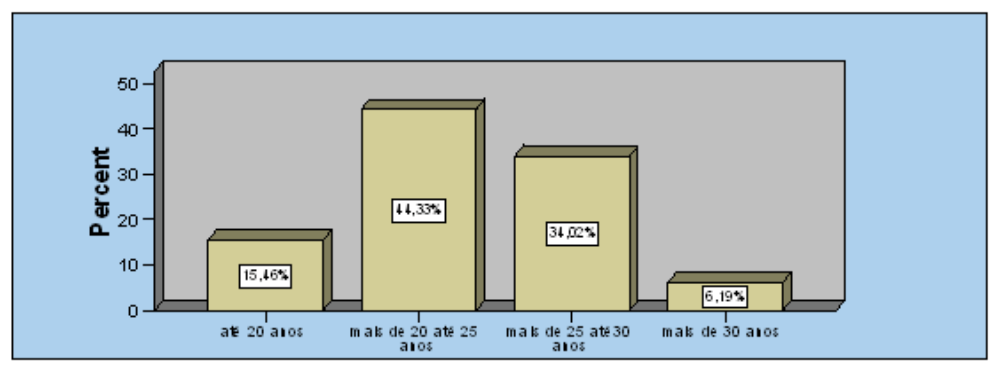

Fonte: Pesquisa de Campo 2005/2006

O percentual de jogadores com idade acima de 30 anos era inexpressivo entre os entrevistados, representando apenas 6,19\%. Destacou-se que esse grupo de jogadores cresceu nos últimos dois anos no futebol brasileiro, devido a um movimento de repatriação de alguns jogadores brasileiros de mais idade, considerados velhos, que estavam atuando no Exterior ${ }^{2}$. Percebeu-se que a média de idade dos jogadores profissionais no Brasil era relativamente baixa, sendo predominante a idade entre 20 e 25 anos.

A idade mínima admitida para o exercício da prática futebolística profissional, no Brasil é de 16 anos. Conforme o Decreto no 2.574/89, art. 47, inciso III, é vedada aos menores, até a idade de 16 anos completos exercerem, a prática esportiva profissional, que pode ser exercida somente depois dos 16 anos completos (NAPIER, 2003, p. 264). A profissionalização do jogador pelo clube é facultativa entre os 16 e os 18 anos, mas se torna obrigatória a partir dos 18 anos de idade.

2 Em 2006, 50\% dos 882 dos atletas que foram transferidos voltaram para o Brasil (RODRIGUES, 2007). 
É visível que o início da carreira é cada vez mais precoce. A profissão de jogador de futebol tem algumas peculiaridades interessantes, entre elas, o fato de que a própria formação se dá nos clubes (empresas empregadoras e não, em Faculdades e centros de formação profissional).

É importante registrar aqui que o atleta em fase de formação, se for maior de quatorze anos e menor de vinte anos de idade, poderá receber uma bolsa como auxílio financeiro, fornecida pela entidade futebolística, antes da sua profissionalização (Art. 29 da Lei no 10.672/03)³.

A idade da profissionalização indica a entrada do atleta no time profissional e o momento em que ele assina seu primeiro contrato profissional.

Conforme o Gráfico 7, a maioria (47,92\%) dos jogadores da amostra se profissionalizou com 18 anos. A idade máxima de profissionalização encontrada entre os entrevistados foi de 21 anos, o que é também um caso excepcional, pois se trata de uma idade avançada para os padrões do futebol atual, conforme ressalta Carravetta (2001 e 2006).

\section{Gráfico 7 - Idade da profissionalização dos jogadores entrevistados}

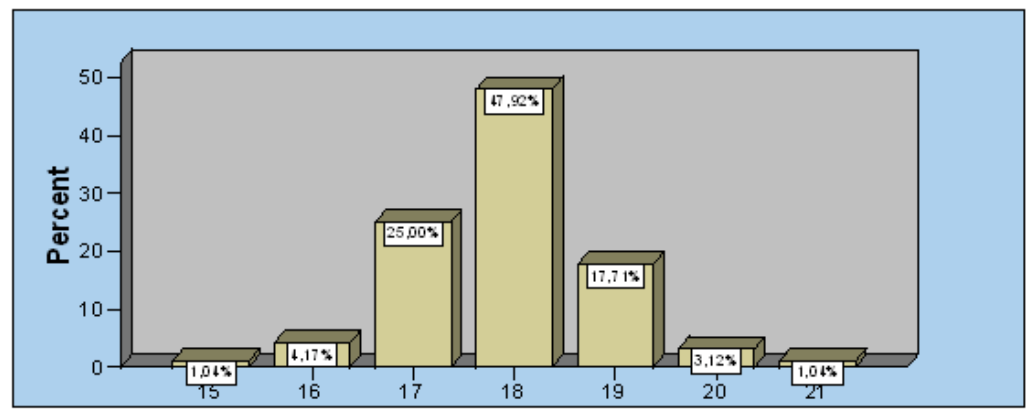

Fonte: Pesquisa de Cam po 2005/2005

\footnotetext{
3 O Art. 29 da Lei no 10.672/03 no seu § 4ㅇ diz o seguinte: "O atleta não profissional em formação, maior de quatorze e menor de vinte anos de idade, poderá receber auxílio financeiro da entidade de prática desportiva formadora, sob a forma de bolsa de aprendizagem livremente pactuada mediante contrato formal, sem que seja gerado vínculo empregatício entre as partes (Lei no 10.672/03)".
} 
É significativo também o grupo de jogadores que se tornou profissional com 17 anos, chegando a 25\% do total de atletas pesquisados. Muitos jogadores assinam contratos cada vez mais cedo, também devido à necessidade de os clubes aproveitarem seus jogadores, já que não dispõem de dinheiro para comprar atletas já consagrados no mercado e também, como uma forma de garantir os direitos sobre o atleta formado, visto que a Lei Pelé facilitou a transferência de jogadores, o que pode significar o roubo de atletas em formação (FÁVERO, 2008; AFIF, 2006; SEITZ, 2006). O contrato de trabalho vincula o atleta ao clube, fazendo com que ele permaneça no clube com o qual assinou contrato até o seu término.

\section{Nível de escolaridade dos jogadores entrevistados}

Um dos fatores preocupantes no campo futebolístico brasileiro é o nível de escolaridade dos atletas. Na verdade, a baixa escolaridade dos jogadores de futebol profissional constitui um elemento que torna esse profissional vulnerável à precarização do trabalho, ao desemprego e à ação de agentes malintencionados, seja durante a carreira, seja depois do seu término. Mesmo não havendo estudos sobre esta questão, os documentos registrados na CBF (Confederação Brasileira de Futebol) comprovam que, em média, os jogadores de futebol não chegam a concluir o primeiro grau (CBF, 2006).

O preocupante é que a maioria dos garotos que se decidem pelo futebol e buscam construir uma vida profissional neste esporte, abre mão de uma série de coisas (viver ao lado da família, privacidade, etc.), entre elas, os estudos. Os estudos deixam de ser prioridade, ficando em segundo ou terceiro plano. Pode-se constatar que são poucos os jogadores que se mantêm estudando durante a carreira, ou retomam os estudos depois do término da carreira de jogador profissional. Os atletas são iludidos pela idéia demasiadamente difundida pela mídia brasileira do "futebol-maravilha" e 
acabam não percebendo que a carreira escolhida é muito curta e extremamente concorrida. Dos atletas que entram nas escolinhas, são poucos os que conseguem tornar-se profissionais, e destes, é pequeno também o percentual dos que terão sucesso profissional e receberão elevados salários (conforme será visto no próximo item, a média salarial é baixa, mais de 80\% dos jogadores profissionais recebem em média de 1 a 3 salários mínimos e somente cerca de 5 a 7\% recebem mais de 20 salários mínimos).

Há uma idéia muito difundida no imaginário social brasileiro, de que o jogador de futebol profissional é aquele indivíduo que ganha bem, é muito famoso, possui tudo que deseja, mulheres e carros importados, etc. Sabe-se que isso não é verdade, trata-se de um mito. Conforme o pesquisador Paulo Favero, da USP (Universidade de São Paulo),

De todas as crianças que jogam futebol na rua, só uma vai virar o Ronaldinho. As pessoas costumam pensar o jogador de futebol como um cara que ganha bem, é famoso, conquista as mulheres. Mas, no fundo, a maioria não vai nem conseguir emprego. [...] O futebol é uma profissão em que o mercado não cresce. Não existem mais empregos. E, se um jogador está em um clube bom, é porque existem muitos outros em clubes ruins (FAVERO, apud MARQUES, 2006, p. 1).

No caso específico do mercado futebolístico brasileiro, são poucos os jogadores que se mantêm estudando durante sua formação e/ou exercício profissional. Os que continuam os estudos são praticamente heróis, considerando as dificuldades enfrentadas. O certo é que a grande maioria interrompe os estudos para se dedicar exclusivamente ao futebol.

Em relação ao nível de escolaridade dos jogadores entrevistados, o Gráfico 8 revela que a maioria $\left(64,95 \%\right.$ ) está na faixa do $2^{2}$ grau ${ }^{4}$ (ensino médio), algo significativo para o jogador de futebol, pois ele não dispõe

4 Na época da pesquisa 2005/2006 ainda estava em vigor a legislação educacional que dividia a educação em primeiro, segundo e terceiro graus. Atualmente a nova legislação utiliza os termos ensino fundamental, ensino médio e ensino superior. 
de tempo para se dedicar aos estudos e até mesmo, devido à idéia muito difundida de que o profissional da bola não necessita de estudo, pois deve saber apenas jogar futebol. Muitos atletas consideram que, para se aprender a jogar futebol não é necessário estudar, pois a aprendizagem se dá na prática, através da constante repetição dos treinamentos. Cabe também destacar que 23,71\% (23 atletas) dos entrevistados têm o 1o grau (ensino fundamental), além do elevado percentual de atletas que responderam que têm ou estão cursando o 3 o grau (ensino superior), chegando a $11,34 \%$ do total de entrevistados.

\section{Gráfico 8 - Nível de escolaridade dos jogadores entrevistados}

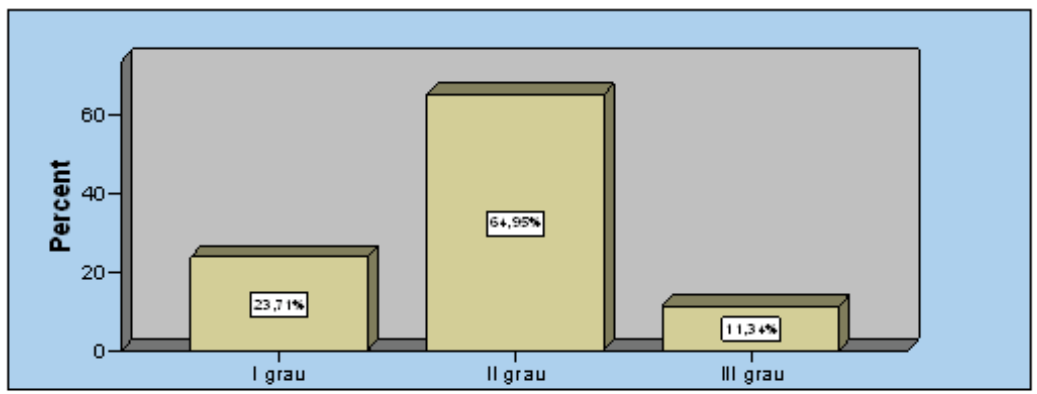

Fonte: Pesquisa de Campo 2005/2006

Mesmo sendo baixo o nível de escolaridade dos jogadores brasileiros, cresce a consciência da importância da escola na vida dos atletas, algo evidenciado a partir das entrevistas e conversas informais com os mesmos. É importante uma formação mais consistente do atleta para melhorar seu desempenho profissional fora dos campos, tais como administrar seu capital, discutir contratos, reivindicar seus direitos como profissional e cidadão e, ainda, para estruturar e planejar a vida para o futuro profissional, depois do término da carreira. 
Entende-se que os clubes mantêm esforços no sentido de proporcionar escolaridade aos jogadores das categorias de base, até mesmo para cumprir obrigações da Lei Pelé (Art. 29, § 7ํㅡ, inciso V) ${ }^{5}$. Mas, é visível que alguns clubes não têm muito interesse nos estudos dos jogadores, pois a escolaridade tem forte influência na conscientização dos mesmos. Os jogadores com baixo nível de instrução tornam-se mais vulneráveis para negociar transferências, para assinar contratos, para assumir compromissos e até para expressar sua vontade.

\section{Nível de renda dos jogadores de futebol entrevistados}

Uma das preocupações desta análise sociológica acerca do futebol é "desnaturalizar" as visões sobre este esporte e assim, contribuir para desvendar alguns mitos que predominam nos discursos da mídia e em algumas análises acerca do futebol brasileiro. Entre os muitos mitos que permeiam o imaginário futebolístico, está o de que todo jogador de futebol é milionário, um profissional sempre bem sucedido que ganha milhões de reais.

O Gráfico 9 apresenta os rendimentos dos jogadores entrevistados na pesquisa de Rodrigues (2007) realizada em 2005/2006, dados estes coletados por meio da pesquisa de campo. Somando-se os dois primeiros estratos de renda (de 1 a 3 SM $^{6}$ e 4 e 6 SM), tem-se então 28,9\% de jogadores que recebem de 1 a 6 SM.

$5 \S 7^{0}$ - A entidade de prática desportiva formadora para fazer jus ao ressarcimento previsto neste artigo deverá preencher os seguintes requisitos: $\mathrm{V}$ - ajustar o tempo destinado à formação dos atletas aos horários do currículo escolar ou de curso profissionalizante, exigindo o satisfatório aproveitamento escolar (Lei no 10.672/03).

6 Salário Mínimo. 


\section{Gráfico 9 - Nível de renda dos atletas entrevistados}

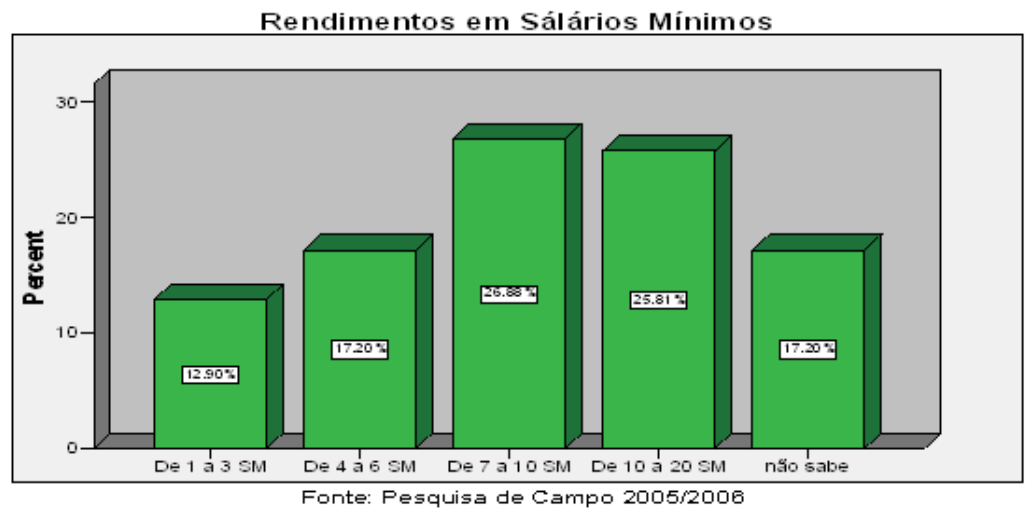

Em relação ao nível de renda dos jogadores de futebol, verifica-se que a média salarial encontra-se entre 7 e 10 salários mínimos (26,88\%). É significativa a parcela de jogadores que ganha de 10 a 20 salários mínimos (25,81\%). Tem-se ainda 17,20\% dos atletas com renda entre 4 e 6 salários mínimos. Pode-se dizer que cerca de 29\% dos jogadores pesquisados ganham de 1 a 6 salários mínimos. Diferentemente do que é divulgado pela mídia brasileira, os nossos jogadores de futebol ganham mal, os salários são baixos e são poucos os atletas que, de fato podem ser classificados como milionários (AFIF, 2006; DAMO, 2005).

Dados do Sindicato de Atletas Profissionais do Rio Grande do Sul mostram que, em 2003, existiam no País cerca de 22.000 jogadores de futebol profissional. Destes, algo em torno de 3.500, estavam empregados e 18.500 se encontravam desempregados. Dentre aqueles, 85\% ganhavam salários de, no máximo, 3 salários mínimos mensais; 13\% ganhavam até 20 salários mínimos mensais e apenas $2 \%$ ganhavam acima deste valor ${ }^{7}$.

7 Fonte: Sindicato dos Atletas de Futebol. 1a Semana de Direito Desportivo, Canoas, 2003. 
A CBF divulgou, no ano de 2000, um documento, que foi posteriormente dirigido ao Tribunal Superior do Trabalho, contendo as condições de trabalho e aspectos salariais dos jogadores brasileiros de futebol. No documento, constava que havia cerca de 22.585 jogadores profissionais em atividade no Brasil, distribuídos pelas seguintes faixas salariais:

Tabela 1 - Faixas salariais dos jogadores de futebol no Brasil (1999, 2000 e 2002)

\begin{tabular}{|c|c|c|c|c|c|c|}
\hline Faixa salarial & $\begin{array}{l}\mathrm{N}^{\circ} \text { Atletas } \\
\text { em } 1999\end{array}$ & $\begin{array}{l}\% \text { em } \\
1999\end{array}$ & $\begin{array}{l}\mathrm{N}^{\circ} \text { Atletas } \\
\text { em } 2000\end{array}$ & $\begin{array}{l}\% \text { em } \\
2000\end{array}$ & $\begin{array}{l}\mathrm{N}^{\mathrm{o}} \text { de atletas } \\
\text { em } 2002\end{array}$ & $\begin{array}{l}\% \text { em } \\
2002\end{array}$ \\
\hline $1 \mathrm{SM}$ & 10.581 & $51,60 \%$ & 10.145 & $44,91 \%$ & 8.638 & $52,9 \%$ \\
\hline 01 a 02 SM & 6.787 & $33,20 \%$ & 9.401 & $41,63 \%$ & 4.987 & $30,5 \%$ \\
\hline 02 a $05 \mathrm{SM}$ & 1.528 & $7,50 \%$ & 1.315 & $5,82 \%$ & 1.289 & $7,9 \%$ \\
\hline 5 a $10 \mathrm{SM}$ & 474 & $2,30 \%$ & 629 & $2,79 \%$ & 436 & $2,7 \%$ \\
\hline 10 a $20 \mathrm{SM}$ & 351 & $1,70 \%$ & 339 & $1,50 \%$ & 293 & $1,8 \%$ \\
\hline $\begin{array}{l}\text { Mais de } 20 \\
\text { SM }\end{array}$ & 765 & $3,70 \%$ & 756 & $3,35 \%$ & 701 & $4,3 \%$ \\
\hline Total & 20.496 & $100 \%$ & 22.585 & $100 \%$ & 16.344 & $100,0 \%$ \\
\hline
\end{tabular}

Fonte: Maciel (2003, p. 57).

Os dados divulgados pela CBF mostram que existiam cerca de 22 mil atletas contratados por cerca de 800 clubes em nosso País no ano de 2000. No entanto, se considerar-se que apenas 50 clubes têm atividades o ano inteiro (participam de competições oficiais nos dois semestres do ano), pode-se concluir que há um número grande de atletas desempregados (DAMO, 2005). Na verdade, tendo em mente que cada clube tem um número de jogadores e varia entre 24 e 30 o número de jogadores com emprego durante todo o ano é mais ou menos de 1.500 (OLIVIER, 2001, p. 56). 
Analisando os dados acima, pode-se ponderar que é elevado o percentual de atletas desempregados durante alguma fase do ano, especialmente quando os campeonatos regionais se encerram. Os pequenos clubes que disputam apenas os campeonatos regionais (estaduais), geralmente só têm atividades durante três meses, o que, muitas vezes, ocorre no primeiro semestre do ano, ficando os atletas desempregados por 9 meses durante o restante do ano. Estes clubes costumam dispensar todo o elenco.

A tabela acima apresenta a distribuição salarial do futebol brasileiro. Verifica-se que existe uma evidente e monstruosa desproporção entre os salários pagos a alguns jogadores e os salários pagos à maioria dos profissionais do futebol. Cerca de 52,9\% dos atletas recebem algo em torno de 1 salário mínimo, enquanto 4,3\% recebem acima de 20 salários mínimos.

A renda dos jogadores de futebol é um dado importante, mas muito difícil de ser obtido. Os atletas e os clubes preferem não revelar exatamente os valores equivalentes aos salários. Dados da CBF revelam que $84,8 \%$ dos jogadores inscritos na entidade ganham até 2 salários mínimos. Neste universo, é necessário que se diga, aparecem jogadores de times semi-amadores. Já na elite do futebol nacional, a primeira divisão, a realidade é outra totalmente diferente. $46,6 \%$ dos jogadores da primeira divisão nacional ganham de 10 a 40 mil reais, o que forma uma classe média muito bem remunerada. $\mathrm{E}$ apenas 1,2\% têm salários inferiores a mil reais. A realidade financeira dos atletas brasileiros é extremamente heterogênea (DAMO, 2005).

A lista dos jogadores de futebol que recebem os maiores salários no Brasil apresenta jogadores com salário dentro do padrão europeu.

Um levantamento da Revista Placar (n. 1300, novembro de 2006, p. 48-55) revelou que apenas dois jogadores do Santos Futebol Clube (Maldonado e Zé Roberto) ganhavam por mês algo equivalente ao que os 25 jogadores profissionais do Vasco da Gama recebiam. Isso mostrou 
o enorme desequilíbrio econômico no futebol brasileiro. Os dois atletas mencionados recebiam mais de 600 mil reais, valor desembolsado pelo Vasco da Gama para pagar seus jogadores.

Em 2006, os clubes brasileiros com as folhas salariais mais robustas (maiores), eram o Santos Futebol Clube, o Sport Club Corinthians Paulista, o Fluminense e o São Paulo Futebol Clube. O Santos estava gastando o dinheiro que recebeu com as vendas de Robinho, Diego, Léo e Elano (mais de 40 milhões de dólares).

João Paulo de Jesus Lopes, diretor de futebol do São Paulo Futebol Clube afirmou que "No São Paulo temos uma política com vários níveis de faixa salarial, de acordo com o status do jogador. Outros clubes também fazem isso, e são justamente aqueles que, em geral, vão bem nos campeonatos de pontos corridos, onde a organização é premiada" (Placar, n. 1300, 11/2006, p. 50).

O jogador mais bem pago no Brasil em 2006 era Zé Roberto, 32 anos, atleta do Santos Futebol Clube. Zé Roberto não conseguiu um clube na Europa que atendesse suas exigências e resolveu voltar ao futebol brasileiro após receber propostas de alguns clubes como São Paulo e Santos. Zé Roberto (em 2006) assinou contrato com o Santos por 10 meses, com salário mensal de 500.000 reais. Esse valor era superior ao que Carlitos Tevez recebia no Corinthians, 400.000 reais por mês. O salário de Zé Roberto estava dentro do padrão europeu.

O campeonato de futebol alemão apresentava, em 2005, os salários mais modestos na Europa. Apenas cinco jogadores recebiam mais do que 180.000 euros (em 2005), o salário de Zé Roberto no Bayern de Munique (Alemanha). 
Tabela 2 - Ranking dos salários no futebol brasileiro 2006

\begin{tabular}{|c|c|}
\hline JOGADOR E CLUBE & SALARIOS RECEBIDOS EM REAIS \\
\hline Zé Roberto (Santos) & 500.000 \\
\hline $\begin{array}{l}\text { Petkovic (Fluminense) e Rogério Ceni } \\
\text { (São Paulo) }\end{array}$ & 300.000 a 350.000 \\
\hline $\begin{array}{l}\text { Amoroso, Roger (Corinthians), Fábio } \\
\text { Costa, Kleber, Maldonado (Santos) e } \\
\text { Romário (recebe dinheiro do Vasco e } \\
\text { Flamengo) }\end{array}$ & 180.000 a 220.000 \\
\hline $\begin{array}{l}\text { Magrão, Carlos Alberto (Corinthians), } \\
\text { Marcos, Juninho Paulista (Palmeiras) e } \\
\text { Sávio (Flamengo) }\end{array}$ & 150.000 a 180.000 \\
\hline $\begin{array}{l}\text { Élber (Cruzeiro), Fernandão (Inter-RS), } \\
\text { Rogério, Pedrinho (Fluminense), Renato } \\
\text { César Ramírez, (Flamengo) }\end{array}$ & 100.000 a 120.000 \\
\hline $\begin{array}{l}\text { Clemer (Inter-RS), Danilo, Mineiro } \\
\text { (São Paulo), Gabriel (Cruzeiro) }\end{array}$ & 80.000 a 90.000 \\
\hline
\end{tabular}

Fonte: (Placar, no $1300,11 / 2006$, p. 51).

Sindicalização dos jogadores

entrevistados e tipos de transferências

Ao aprovar a Lei no 9.615/1998 (Lei Pelé), Pelé, o então Ministro dos Esportes, disse em um de seus discursos que os atletas brasileiros eram alienados e que, com aquela Lei, estava pagando uma dívida que tinha com os nossos atletas. É verdade que praticamente nenhum atleta se mobilizou para defender a proposta que a Lei trazia, de extinção do passe. Isso se deve também ao fato de que os atletas brasileiros têm pouca capacidade de mobilização e principalmente porque a organização sindical dos jogadores brasileiros é ainda incipiente. Poucos são os futebolistas que lutam de fato pelos seus direitos, ou seja, não há uma consciência de classe entre os jogadores profissionais de futebol. 
A organização dos jogadores brasileiros enquanto categoria profissional apresenta baixo nível, se comparado com os da Europa, Argentina e Uruguai, países onde os jogadores defendem seus direitos e até organizam greves. A maioria de nossos atletas tem um baixo nível de escolarização.

Pode-se sugerir a ideia de que o jogador brasileiro imagina, que de uma hora para outra, pode tornar-se um multimilionário e passa a pensar apenas nele mesmo, na família e em irmãos e amigos, sem se preocupar com os colegas de profissão, pois considera que o que conseguiu no futebol é resultado exclusivamente do seu esforço. Pode-se analisar esse aspecto da seguinte forma: o atleta profissional de futebol é um verdadeiro bóia-fria do futebol, que não tem tempo sequer para formar a consciência de classe e não se mobiliza por nada.

Mesmo não sendo uma classe de trabalhadores que tem tradição sindical, os jogadores de futebol estão cada vez mais procurando os sindicatos. Estes são vistos como veículos de representação dos direitos dos atletas.

O presidente do Sindicato dos Atletas Profissionais do Estado de São Paulo, Rinaldo Martorelli, entende que existem grandes dificuldades para o atleta ingressar no Sindicato e disputar eleições. Segundo ele, trata-se de uma profissão que exige dele o tempo inteiro de dedicação e fica difícil encontrar tempo para esses debates. Martorelli é vice-presidente da Federação Nacional de Jogadores e membro titular do Comitê de Litígios da Fifa. Este comitê é o mais importante órgão da Justiça Desportiva Mundial, sendo o responsável pelas sentenças das disputas entre jogadores de futebol e clubes. Martorelli também é membro titular da Federação Internacional dos Futebolistas Profissionais, o sindicato mundial dos jogadores, que tem sede na Holanda.

Conforme pode ser visualizado no Gráfico 10, 53,61\%, dos jogadores de futebol são sindicalizados. Já 41,24\% dos jogadores responderam que não são filiados aos sindicatos. 


\section{Gráfico 10-Percentual de atletas entrevistados sindicalizados}

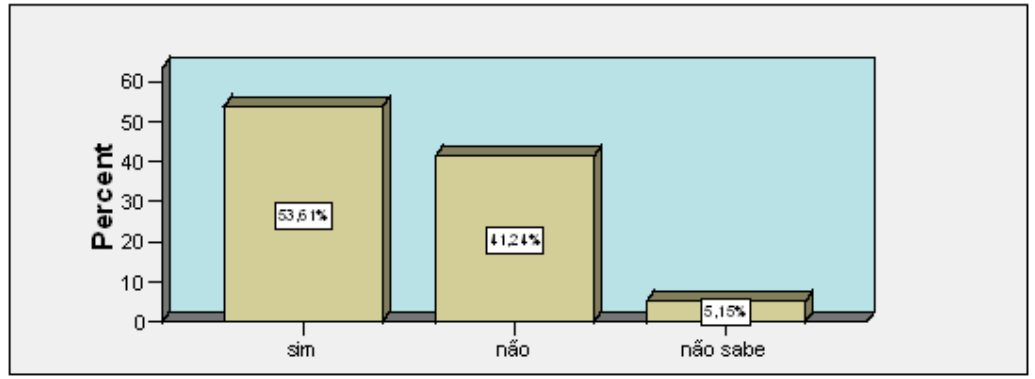

Fonte: Pesquisa de Campo 2005/2006

A seguir, analisam-se algumas formas de transferências de jogadores entre as entidades desportivas profissionais.

As principais determinações da Lei no 9.615/24/03/1998, com alterações da Lei no 9.981/00, da Lei no 10654/01 e da Lei no 10.672/03: o Art. 38 da Lei no 9.615/1998 diz que a "cessão ou transferência de atleta profissional, na vigência do contrato de trabalho, depende de sua formal e expressa anuência (Lei no 9.981/00)". O artigo seguinte é mais detalhista e reza que a

transferência do atleta profissional de uma entidade de prática desportiva para outra do mesmo gênero poderá ser temporária (contrato de empréstimo) e o novo contrato celebrado deverá ser por período igual ou menor que o anterior, ficando o atleta sujeito à cláusula de retorno à entidade de prática desportiva cedente, vigorando no retorno o antigo contrato, quando for o caso. (Art. 39 da Lei no 9.981/00)

Analisando os tipos de transferências de jogadores, constata-se que o empréstimo é o principal tipo de transferência, presente em 42,06\% dos casos constatados pela pesquisa (Gráfico 11). Nessa modalidade, os clubes assinam contratos longos com os atletas e os cedem (emprestam) 
para outros clubes durante a vigência do contrato. Trata-se da negociação dos direitos federativos do atleta.

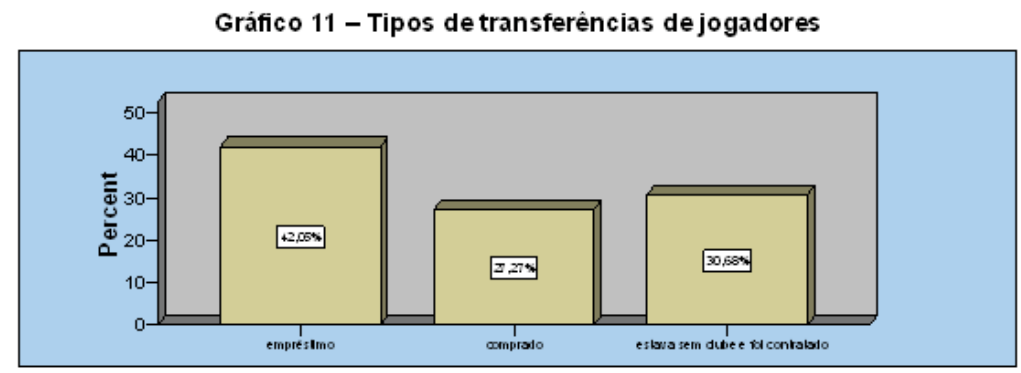

Fonte: Pesquisa de Campo 2005/2006

A investigação constatou que $30,66 \%$ dos jogadores estavam sem clube e foram contratados. A compra de jogadores continua sendo um tipo de transferência importante no mercado futebolístico nacional. A pesquisa revelou que 27,27\% dos jogadores foram comprados (Gráfico 11). Com base nos resultados da pesquisa, defende-se a idéia de que o número de jogadores que estavam sem clube e foram contratados por outro é um importante elemento que resultou da Lei Pelé, portanto, um dos impactos do fim do passe. Trata-se de um resultado evidente da liberdade de trabalho proporcionada parcialmente pela nova legislação.

Fim do passe e as transferências internas e externas de jogadores brasileiros

Passagem dos jogadores pelo futebol estrangeiro

No caso de transferências de jogadores brasileiros para o futebol do exterior, é importante ressaltar que a regulamentação obedece as determi- 
nações da Lei no 9.615, de 24 de março de $1998^{\circ}$, com alterações pela Lei no 9.981/009 , e pela Lei no $10.654 / 01^{10}$, e da Lei no $10.672 / 03^{11}$, sendo o artigo 40 o principal mecanismo que define as normas da cessão ou transferência de atleta profissional para entidade de prática desportiva estrangeira.

A presente pesquisa constatou que 32,99\% dos jogadores já passaram pelo futebol estrangeiro (Gráfico 12). Trata-se de um elevado percentual de atletas que atuaram em outro país, o que evidencia que o futebol é, de fato, um mercado de trabalho globalizado (GIULIANOTTI, 2002; DAMO, 2005; RODRIGUES, 2007). Cabe destacar que $67 \%$ dos atletas não jogaram no exterior, mas que boa parte deles deseja ainda trabalhar em outro país.

8 A Lei no 9.615, de 24 de março de 1998 institui normas gerais sobre desporto e dá outras providências. Esta Lei define a Natureza e as Finalidades do desporto, reconhecendo o desporto como educacional, de participação e de rendimento. Dispõe sobre os procedimentos de contratação, liberação e transferências internas e externas de atletas. O aspecto mais importante que interessa nesta Lei é o fim do passe.

9 A Lei no 9.981/00 altera dispositivos da Lei n 9.615, de 24 de março de 1998, e dá outras providências. $\mathrm{O} \S 5^{\circ}$ diz que "Quando se tratar de transferência internacional, a cláusula penal não será objeto de qualquer limitação, desde que esteja expresso no respectivo contrato de trabalho desportivo." 10 A Lei no 10.654/01 diz que As condições para transferência do atleta profissional para o exterior deverão integrar obrigatoriamente os contratos de trabalho entre o atleta e a entidade de prática desportiva brasileira que o contratou.

11 A Lei no 10.672/03, no artigo 40, o $§ 2$ o reza que "Se a entidade de prática desportiva cedente de atleta profissional para entidade de prática desportiva estrangeira tiver sido cessionária do atleta, no prazo inferior a doze meses, em transferência definitiva ou empréstimo, oneroso ou gratuito, para qualquer outra entidade de prática desportiva, será caracterizada como entidade repassadora fazendo jus a vinte e cinco por cento do valor pactuado para a cessão ou transferência internacional, ficando a entidade formadora com direito de receber setenta e cinco por cento do valor pago pela entidade estrangeira, desde que a entidade formadora do atleta não tenha sido previamente indenizada" (Lei no 10.672/03). 
Gráfico 12 - Passagem pelo futebol do exterior

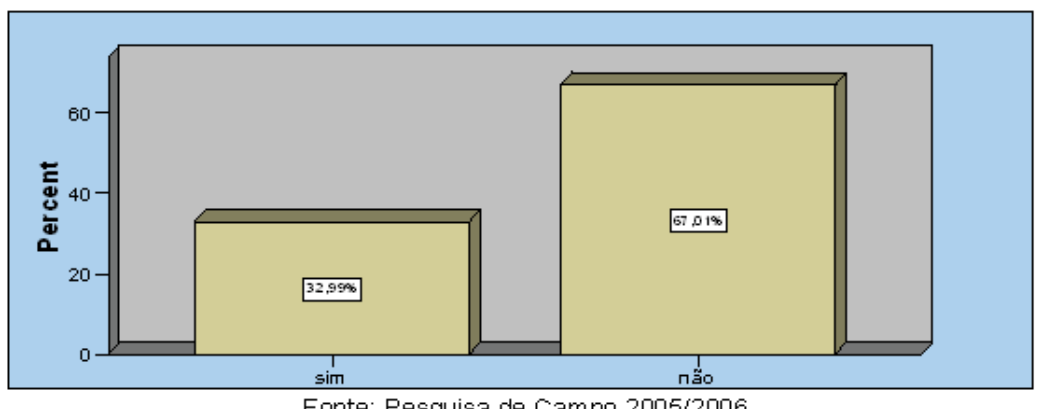

Fonte: Pesquisa de Campo 2005/2006

O processo de globalização tem facilitado as transferências internacionais de jogadores de futebol, abrindo novos mercados para jogadores estrangeiros. Os atletas brasileiros ${ }^{12}$, obviamente, são beneficiados por esse processo (GIULIANOTTI, 2002). É visível que, a cada ano, o número de brasileiros que vão para o futebol do exterior é maior. Por globalização, entendemos a crescente interdependência entre povos diferentes, regiões e países em todo o mundo, na medida em que as relações econômicas e sociais abrangem todo o mundo (GIDDENS, 2004, p. 693). Os clubes de futebol funcionam como empresas transnacionais que consolidam o comércio internacional de atletas (ROBERTSON; GIULIANOTTI, 2006, p. 13-18).

É cada vez maior o número de jogadores brasileiros que já atuaram no exterior. Em 2000, um em cada quatro jogadores já havia jogado em algum clube do exterior. É grande também a lista de atletas que atuaram fora e retornaram ao Brasil. Muitos não conseguem se firmar nas suas equipes e voltam, mas outros retornam porque são atraídos pelos salários pagos por aqui, mesmo que continuem defasados em relação à Europa (Placar, 2000, p. 84).

12 Não apenas os atletas são beneficiados com as transferências internacionais, mas os clubes e a economia nacional, pois só de transferências, as vendas de jogadores geraram U\$ 1 bilhão entre 1994 e 2005 (FÁVERO, 2008). 
No ano de 2000, dos jogadores que atuavam na primeira divisão (Série A) do campeonato brasileiro, 72,7\% deles nunca tinham atuado no exterior. E 27,3\% dos jogadores passaram pelo futebol do exterior ${ }^{13}$.

A Tabela 3 mostra a evolução do número de jogadores brasileiros com passagem pelo futebol do exterior. Percebe-se que o percentual de atletas brasileiros com passagem pelo exterior sobe de 27,3\%, em 2000, para 33\%, em 2006. Trata-se de um dado relevante para se pensar a fase atual da globalização do futebol (GIULIANOTTI, 2002; ROBERTSON; GIULIANOTTI, 2006).

Tabela 3 - Evolução da passagem pelo futebol estrangeiro

\begin{tabular}{lll}
$\begin{array}{l}\text { Quem já jogou em outro CBF/PLACAR (2000) } \\
\text { país }\end{array}$ & PESQUISA (2005/2006) \\
\hline $\begin{array}{l}\text { Nunca jogou no exterior } \\
\text { Já jogou no exterior }\end{array}$ & $72,7 \%$ & $67 \%$ \\
\hline
\end{tabular}

Fonte: CBF/Placar (2000, p. 84) e Pesquisa de campo (2005/2006).

Conforme Tabela 3, 33\% dos jogadores pesquisados jogaram no futebol do exterior, dado condizente com a realidade brasileira, pois o Brasil é conhecido no mundo futebolístico como o país do futebol e um dos maiores exportadores de jogadores de futebol.

Jogar no exterior é um sonho da maioria dos jogadores brasileiros, fazendo parte do projeto profissional de 51,55\% dos jogadores pesquisados (RODRIGUES, 2007, p. 236). Tendo isso em mente, busca-se relacionar as mudanças atuais na legislação esportiva brasileira com as aspirações dos jogadores por atuar no exterior, devido aos salários elevados e às ótimas condições de trabalho e possibilidades de ascensão no mundo do futebol. É grande a desproporção que existe entre os salários pagos na Europa e no Brasil.

13 Entre os atletas do Grêmio - RS no ano 2000, 11 já tinham jogado no exterior (Placar, 2000, p. 84). 
Com a nova legislação, a transferência de atletas brasileiros para o exterior se intensificou e ganhou uma nova dimensão: a precocidade com que jogadores de futebol de 16 a 18 anos deixam os campos brasileiros para atuarem no futebol europeu, sul-americano e asiático. Está acontecendo, no Brasil, um movimento parecido com o que já ocorreu na África. Percebe-se que os melhores talentos da África transferem-se para a Europa, cada vez mais cedo. Isso explica, em parte, a presença de tantos africanos em seleções européias, como por exemplo, a da França. As transferências de jovens atletas brasileiros para o futebol europeu e asiático têm implicado no denominando movimento de "africanização do futebol brasileiro" (Folha de São Paulo, 15/07/2003) ${ }^{14}$.

A história recente do futebol mostra que o Brasil tornou-se país exportador de jogadores de futebol, a partir da década de 1930. Com o fim do passe, os clubes (e mercados) compradores foram beneficiados pelo fato de que não era mais necessário "comprar" o "passe" do atleta, mas pagar a rescisão contratual (em caso de o atleta encontrar-se empregado em um clube brasileiro) ou acertar o pagamento do salário com o jogador (se este não tiver contrato com algum clube). Se o fim do passe possibilitou ao atleta (trabalhador) escolher e decidir onde trabalhar, ele estabeleceu a liberdade de trabalho e criou condições para desburocratizar as transferências internacionais, favorecendo o aumento das exportações de atletas, porém não pode ser apontado (culpado) como a única e principal causa (RODRIGUES, 2007, p. 236; SEITZ, 2006; MACIEL, 2003; SEITZ, 2006).

Se os jogadores pretendem mesmo jogar no futebol estrangeiro, é porque, quando o atleta se transfere para outro país, crescem suas possibilidades de enriquecimento e também de ser convocado para a seleção

14 O presidente do Clube dos Treze, Fábio Koff, se referiu a essas transferências como uma africanização do futebol brasileiro. 
brasileira - obviamente que isso depende muito do país em que se está atuando. O futebol europeu favorece muito o jogador, no sentido de que Ihe dá mais visibilidade, algo importante para se chegar ao selecionado nacional (DAMO, 2005, GIULIANOTTI, 2002).

Percepção dos jogadores pesquisados sobre transferências e exportação de atletas depois do fim do passe

No mundo futebolístico, é inegável a participação brasileira no mercado mundial como grande exportador de jogadores de futebo ${ }^{15}$. As estatísticas da FIFA e da CBF mostram que o Brasil tem cada vez mais exportado atletas. Nos últimos quatro anos, a média de jogadores exportados por ano é de cerca de 800 jogadores. Em 2006 foram 822 atletas exportados e em 2007 foram 1088 atletas (RODRIGUES, 2007, p. 161) ${ }^{16}$.

O êxodo de jogadores brasileiros para o exterior é crescente, aumenta a cada ano. Muitos jornalistas e dirigentes alegam que a Lei Pelé é a principal causa. Entende-se que de acordo de que a referida lei facilita as transferências internacionais, pois ao extinguir o passe, ela flexibiliza os contratos e negociações entre clubes e jogadores, mas não é a principal causa (SEITZ, 2006; AFIF, 2006).

Concepção dos jogadores sobre transferências internas de atletas depois do fim do passe no Brasil

É importante destacar que o fim do passe também criou novas condições para as transferências internas de jogadores brasileiros (mobilidade inter-clubes e inter-regional). Conforme mostra o Gráfico 13, 64,95\% dos jogadores entrevistados responderam que o fim do passe facilitou muito as transferências

15 Entre os países que mais importam jogadores do Brasil estão Portugal, que desde 2002 lidera o ranking, com uma média de 140 jogadores por ano, algo em torno de 35\% das transferências, Itália, França, Alemanha, Japão e Espanha (FÁVERO, 2008).

16 Ver especialmente no capítulo 3, a Tabela 1, p. 161. 
internas de jogadores no futebol brasileiro. É um dado significativo, mais que o dobro do percentual de atletas que defendem que o fim do passe facilitou pouco as transferências internas de jogadores no Brasil (30,93\%).

Defende-se o argumento de que a flexibilização dos contratos e das relações de trabalho permitidas pela Lei Pelé tem contribuído muito para essa substancial mobilidade interna de atletas (RODRIGUES, 2007, p. 275).

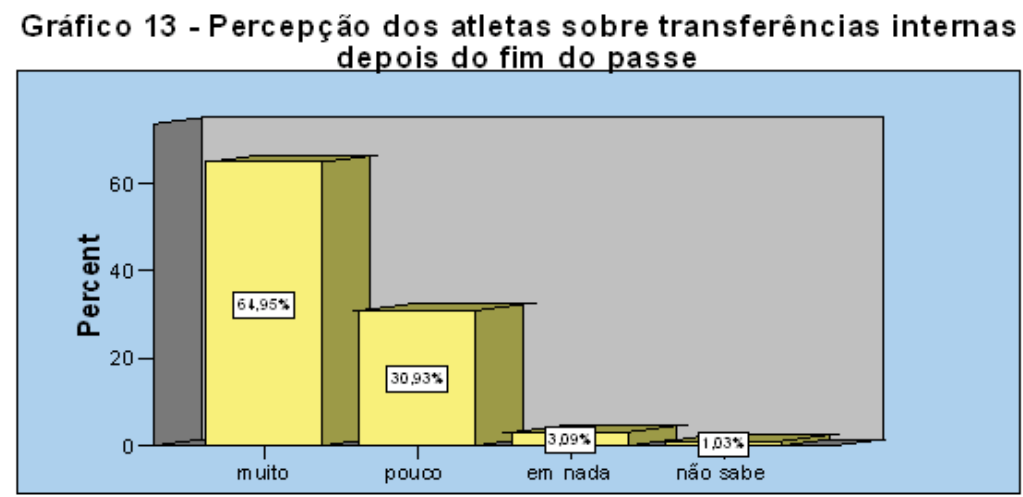

Fonte: Pesquisa de Campo 2005/2006

A seguir, apresenta-se um Gráfico (14) com as percepções dos jogadores entrevistados acerca das possibilidades de transferência para um grande clube com a entrada em vigor do fim do passe. 


\section{Gráfico 14 - Fim do passe e transferências para grandes clubes}

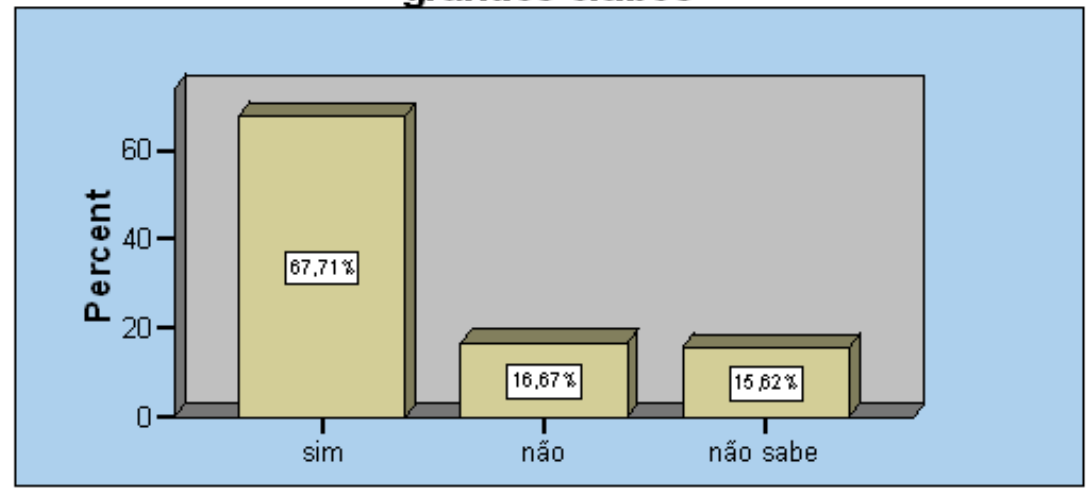

Fonte: Pesquisa de Campo 2005/2006

A maioria dos jogadores, cerca de $67,71 \%$, acredita que o fim do passe aumentou as possibilidades de transferência dos jogadores brasileiros para um grande clube nacional. Isso se atribui a diversos fatores, entre eles o fato de a Lei Pelé ter estabelecido uma redução na idade para as transferências, de 18 para 16 anos. Outro fator é a mudança no sistema de transferências, o estabelecimento da liberdade de trabalho para o atleta, entre outros. Para 16,62\% dos entrevistados, o fim do passe não aumentou as possibilidades do atleta se transferir para um grande clube. É bastante elevado o percentual de atletas que não souberam responder, chegando a $15,62 \%$ dos atletas, quase igual ao dos que consideram que o fim do passe não aumentou as possibilidades de transferência para um grande clube (RODRIGUES, 2007, p. 277). 
Percepção dos jogadores sobre transferências internacionais de atletas brasileiros após o fim do passe

Analisa-se a percepção dos atletas pesquisados sobre as transferências internacionais após o fim do passe, especialmente acerca das principais causas desse fenômeno.

Muitos autores apontam outros fatores que favorecem a emigração do Brasil (ALCÂNTARA, 2006; CARVALHO; GONÇALVES, 2006; SOUTO, 2004; DAMO, 2005; HELAL, 1997; LEONCINI; SILVA, 2005; PRONI, 2000): a administração amadora e patrimonial dos clubes; a extinção do "passe" pela Lei Pelé (Lei n. 9.615, de 24 de março de 1998); a ação do empresário e do Agente FIFA; o número limitado de postos de trabalho nos clubes; o surgimento de uma indústria para formação de jogadores e os baixos salários. Por isso, segundo Alcântara (2006, p. 299), o negócio do futebol passou a ter forte impacto sobre as exportações brasileiras. As vendas de jogadores para o exterior geraram algo em torno de US\$6,4 bilhões, 40\% do total, em 2005.

As estatísticas apontam uma crescente evolução da exportação de jogadores brasileiros nos últimos anos (RODRIGUES, 2007; FÁVERO, 2008). O Gráfico 15 indica que os atletas entrevistados têm consciência de que a exportação de jogadores brasileiros cresceu depois do fim do passe. Cerca de $62,89 \%$ dos jogadores acreditam que cresceu a exportação de jogadores brasileiros porque a Lei Pelé facilitou as transferências ao decretar o fim do passe e estabelecer a liberdade de trabalho.

Cabe destacar que é elevado o percentual de atletas (31,96\%) que responderam que nada mudou nas transferências internacionais de jogadores no Brasil depois do fim do passe, pois o Brasil sempre foi um país exportador de jogadores. Parte-se do pressuposto de que o Brasil historicamente produz bons jogadores e se configura como um dos maiores exportadores de jogadores de futebol do mundo, mas que a Lei Pelé 
contribui muito com o crescimento numérico nesse processo, por razões já mencionadas anteriormente.

\section{Gráfico 15 - Transferências internacionais depois do fim do passe}
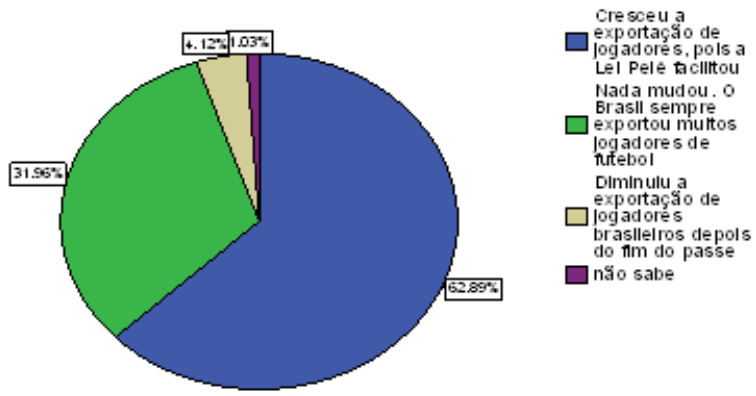

Fonte: Pesquisa de Campo 2005/2006

É importante destacar que os atletas, através do sindicato, precisam posicionar-se diante da questão das transferências internacionais de jogadores. A postura do sindicato em relação ao movimento crescente de transferências de jogadores brasileiros para o exterior durante o campeonato brasileiro é bastante cautelosa. Segundo o presidente do sindicato dos atletas profissionais de São Paulo, Rinaldo Martorelli ${ }^{14}$

[...] o jogador deve permanecer o campeonato inteiro no clube. Mas há antecedentes. O jogador tem a segurança de que os contratos serão cumpridos e seus direitos serão garantidos pelo clube? Não. O Atlético-MG, por exemplo, perdeu jogos seguidos e já dispensou uma leva de atletas. Há um caso no

17 Rinaldo Martorelli é presidente do Sindicato dos Atletas Profissionais do Estado de São Paulo há 13 anos. É vice-presidente da Federação Nacional de Jogadores e membro titular do Comitê de Litígios da Fifa, órgão máximo na Justiça Desportiva para sentenciar disputas entre clubes de futebol e jogadores profissionais. 
clube que não recebe salários e o que tem direito há sete meses. Não tem como falar para um atleta não aceitar uma proposta em uma estrutura tão desarrumada, na qual ele não tem garantias de que será respeitado como profissional (Rinaldo Martorelli, Entrevista com o autor, 07/02/2006).

É a atual estrutura do futebol brasileiro a responsável maior pelo êxodo de nossos jogadores. Sabe-se que as condições de trabalho e os salários no mercado futebolístico europeu são muito melhores do que a nossa realidade (FÁVERO, 2008; SEITZ, 2006). Isso é um dos fatores que atrai os atletas brasileiros. Segundo Rodrigues (2007, p. 280)

As transferências de jogadores durante o campeonato atrapalham os clubes e deixam os consumidores (torcedores) também confusos e irritados. O nível técnico do futebol é prejudicado pela saída dos melhores jogadores brasileiros. Se as transferências de jogadores brasileiros para o exterior ocorressem somente no final de temporada a situação seria outra. A CBF e os clubes precisam tomar medidas para evitar a fuga de atletas durante o campeonato que sejam compatíveis com os interesses de todos, inclusive dos jogadores (RODRIGUES, 2007, p. 280).

Percebe-se que o Brasil ainda não definiu claramente qual o seu modelo de futebol. Trata-se de uma indefinição, algo característico de um campo (no sentido de Bourdieu, 1988), no qual os diferentes atores sociais têm interesses diferentes e buscam maximizar seus capitais. Não se sabe se queremos um modelo exportador de atletas ou se queremos um modelo que prima pela manutenção dos atletas nos nossos gramados. Os dirigentes falam uma coisa e fazem outra. Dizem que não querem negociar seus jogadores, depois negociam e argumentam que não tinham alternativas.

Além de a Lei Pelé ter facilitado as transferências de jogadores brasileiros para o exterior (mesmo que antes dela já fosse significativo o êxodo de atletas), destacam-se outros fatores, entre os quais a globalização (hoje o mundo inteiro está conectado), o enriquecimento maior dos clubes estran- 
geiros e o fato desses clubes terem aperfeiçoado suas fontes de receita (TV, exploração comercial das arenas, marketing etc.), transformando-os em potências financeiras e, conseqüentemente, com alto poder de compra (GIULIANOTTI, 2002; FÁVERO, 2008; DAMO, 2005; RODRIGUES, 2007).

Acredita-se que, se o Brasil assumisse de forma clara o modelo exportador, seria um passo importante para abolir as distorções nos discursos, pois a venda de atletas para o exterior também tem seu lado positivo, no sentido de que possibilita a entrada de dólares no país, dinamizando o mercado futebolístico e a economia em geral (CARVALHO; GONÇALVES, 2006; HELAL, 1997; PRONI, 2000). Portanto, para a economia brasileira é benéfica essa entrada de recursos, assim como para a balança comercial e para o superávit do país. Há um envolvimento geral do futebol com a economia mundial e, para o Brasil, fica difícil concorrer com moedas como o dólar e o euro. Os jogadores brasileiros saem do país também devido à desorganização do nosso futebol (HELAL, 1997). Atualmente, muitos atletas são maltratados nos clubes, não recebem em dia, não têm garantias, isso os leva a aceitar as propostas do exterior (SEITZ, 2006; FÁVERO, 2008).

Por outro lado, se o futebol brasileiro adotasse o modelo de organização empenhado em manter os seus principais jogadores nos times nacionais, ocorreria uma profunda reestruturação na gestão do futebol. Os clubes deveriam organizar-se melhor, no sentido de tratar o jogador com mais respeito, de forma mais profissional, buscando cumprir os contratos. Trata-se da necessidade de uma reestruturação geral no modelo brasileiro, especialmente na relação entre clubes e atletas (HELAL, 1997; PRONI, 2000; LEONCINI e SILVA, 2005). Os clubes precisariam aceitar sanções esportivas em caso de descumprimento de contratos assinados com atletas. O que seria possível com uma Câmara Arbitral. A punição da Justiça Trabalhista, aos clubes e aos atletas seria feita por meio da penhora de 
patrimônio. Uma série de medidas deveria ser tomada para que o clube ficasse preso ao cumprimento do contrato (o mesmo válido para o atleta). Em caso de descumprimento, os clubes poderiam até ser suspensos de competições oficiais (RODRIGUES, 2007, p. 281).

Muitos clubes brasileiros assumem compromissos inviáveis pois não possuem condições para cumprir com os mesmos, isso devido à falta de clareza no modelo de futebol que vigora no Brasil e também em decorrência da má gerência dos clubes brasileiros. Os clubes vivem sob um regime predatório. Somente se tira e pouco se põe. Costuma-se vender os melhores jogadores sem investir os recursos referentes à venda do atleta. Quando um atleta novo, recém revelado, é convocado para a seleção brasileira logo recebe propostas para se transferir. Os dirigentes e empresários não exitam muito e negociam o atleta, pois se interessam pelo lucro com as transferências e não com o futebol em si (HELAL, 1997). Pouco se faz para segurar os atletas brasileiros nos nossos clubes, pois o interesse pessoal do cartola que vende o atleta é dominante nesse modelo de estrutura do futebol. Recusa-se o clube empresa temendo o controle externo, a obrigação de prestar contas (AIDAR, 2000; CARVALHO; GONÇALVES, 2006; FERNANDES, 2000).

No futebol europeu, e isso não se deve somente a razões econômicas, existe certa estabilidade nos vínculos do clube com os jogadores. As normas de relações entre jogadores e clubes já estão consolidadas e são cumpridas com mais rigor do que no futebol brasileiro. Nesse sentido, é importante lembrar aqui o modelo espanhol, o qual adota um contrato coletivo que garante mais estabilidade no vínculo do clube com o atleta (GIULIANOTTI, 2002; PRONI, 2000; HELAL, 1997).

Um modelo interessante de relações entre clubes e atletas é o adotado no futebol espanhol, no qual existe o contrato coletivo de trabalho. As leis trabalhistas regulamentam os contratos de trabalho dos futebolis- 
tas profissionais e determinam a obrigatoriedade de um contrato coletivo para os jogadores. Cada atleta tem seu contrato de trabalho específico, mas dentro das normas gerais estabelecidas no contrato coletivo. Esse modelo também está presente na Itália, Argentina e na Inglaterra. Entende-se que o mesmo poderia ser adaptado ao nosso futebol e implementado o sistema de convenção coletiva. No entanto, os dirigentes do esporte brasileiro resistem e não aceitam esse procedimento ${ }^{18}$.

Em relação aos casos envolvendo atletas e clubes, uma das lutas da Federação Internacional dos Futebolistas Profissionais é tentar padronizar os procedimentos referentes às transferências e aos litígios em todo mundo. Isso permitirá maior eficiência na ação da Federação em defesa dos interesses dos jogadores e maior coerência na análise e resolução dos casos. Uma das dificuldades atuais se dá devido ao fato de que basicamente em cada país há uma legislação diferente (MACIEL, 2003; PAIVA, 2001; MACHADO, 2000). É evidente que cada país tem uma legislação federal particular que precisa ser respeitada e também uma justiça desportiva própria ${ }^{19}$.

As causas desse crescimento acelerado da exportação de atletas são diversas. Segundo Rodrigues (2007, p. 282), muitos dirigentes e jornalistas esportivos apontam a atual legislação como a principal culpada, alegando que ao abolir o passe, a Lei Pelé acabou com o poder neo-escravocrata dos clubes sobre os jogadores (MACIEL, 2003; PAIVA, 2001; MACHADO,

$18 \mathrm{O}$ presidente do sindicato dos atletas profissionais de do estado de São Paulo, Rinaldo Martorelli defende a implementação do contrato coletivo no futebol brasileiro (entrevista ao site www.cidadedofutebol.com.br, acesso em 14/09/2006).

19 A Fifa tem orientado as confederações a terem cuidado para que os casos não sejam encaminhados à Justiça Comum, mas também diz que, caso isso ocorra, que os clubes e confederações acatem as decisões da Justiça Comum em relação a transferências e litígios de atletas. A Fifa recomenda que cada federação nacional tenha uma Câmara Arbitral para resolver problemas entre clubes e atletas, seguindo as diretrizes do Comitê de Resolução de Litígios da Fifa. Isso ajudaria a padronizar certas soluções básicas, evitando muitos problemas (Rinaldo Martorelli, entrevista ao site www.cidadedofutebol.com.br, acesso em 14/09/2006). 
2000). Defendem que foi a partir da entrada em vigor da Lei Pelé que as fronteiras foram superadas e ocorreu a intensificação das exportações. Entende-se que essa não é a única causa, e que é necessária uma análise mais abrangente que considere outros elementos. Se observar-se com cautela os números relativos à saída de atletas brasileiros no período anterior e posterior à Lei Pelé, é possível verificar que há diferenças no número de transferências, mostrando uma evolução (GURGEL, 2006; D'OTTAVIANO, 2001; FÁVERO, 2008). Em 1989 saíram do Brasil 132 jogadores profissionais para atuar no exterior, e esse número chegou aos 851 em 2006 (RODRIGUES, 2007, p. 161). No entanto, esta análise contextualiza esses dados, e aponta que a Lei Pelé entra em vigor em um contexto de consolidação da globalização da economia (GIDDENS, 2004 e 2001) e do futebol e de flexibilização das relações de trabalho (reestruturação produtiva), o que pode explicar esse aumento substancial nas exportações nos últimos anos. Essa diferença está diretamente atrelada à evolução cronológica do mercado (FÁVERO, 2008; GURGEL, 2006; SEITZ, 2006, p. 1).

Conforme análise de Oliver Seitz,

De 1989 até o início da Lei Zico ${ }^{20}$, transferiam-se em média uns 190 jogadores por ano. Durante a Lei Zico, essa média pulou para 385, um acréscimo de mais de 100\%. Do início da Lei Pelée ${ }^{11}$ até hoje, a média pulou para uns 750 jogadores por ano, ou seja, cresceu cerca de 95\%. Portanto, olhando assim superficialmente, é possível concluir que qualquer crítica feita à Lei Pelé é falha e carece de base estatística confiável, uma vez que o mercado aumentou mais durante a época da Lei Zico. (SEITZ, 2006, p. 1)

20 A Lei Zico, $n^{\circ}$ 8.672/93, tentou democratizar as relações entre dirigentes e atletas, criando condições para a profissionalização do futebol.

21 Lei no 9.615/1998. 
Em termos proporcionais, as transferências de jogadores brasileiros realmente foram maior durante a vigência da Lei Zico (RODRIGUES, 2007 , p. 161). Na verdade, com essa análise pretende-se desvendar questões acerca da nova legislação futebolística brasileira e mostrar que existe um elevado nível de desinformação nos estudos acerca do futebol profissional brasileiro. Busca-se apontar alguns subsídios que nos permitam questionar o argumento de que a grande responsável pela evasão de jogadores do futebol brasileiro é a Lei Pelé. Neste artigo, admite-se que esta lei contribuiu com esse movimento de aceleração das transferências de jogadores brasileiros para o exterior, porém não é a causa principal (FÁVERO, 2008; AFIF, 2006; GURGEL, 2006; PRONI, 2000).

Pode-se, então, enfatizar outros fatores que contribuem com o movimento acima mencionado. O "caso Bosman"22" contribui com a criação de uma nova configuração no mercado futebolístico mundial a partir de 1995. Pode-se destacar a sentença Bosman ${ }^{23}$ como um dos principais fatores que impulsionam as transferências de jogadores nos últimos anos (ERICSON, 2000; CAMPEBELL; SLOANE, 1997). Trata-se de uma sentença judicial que permite o livre trânsito de jogadores dentro da Comunidade Européia, e pode ser apontado como um dos grandes responsáveis pelo aumento da circulação internacional de jogadores de futebol dentro e para fora do mercado europeu (GIULIANOTTI, 2002; FÁVERO, 2008).

Comparando dados da realidade brasileira referentes às influências da Lei Pelé, da Lei Zico e do Caso Bosman sobre as transferências internacionais de jogadores brasileiros, é possível destacar que entre 1989 e 1995 (momento posterior a sentença Bosman), a média anual de transfe-

22 O Caso Bosmann não pode ser considerado exatamente como o pioneiro na libertação contratual de jogadores, pois isso já ocorreu na Inglaterra por volta da metade do século XX.

23 Acerca do Caso Bosman, ver especialmente a seção 2.4 Consequências do Caso Bosman para o mercado de transferências de jogadores, do capítulo 2 A Globalização do futebol e a migração internacional de jogadores, da nossa tese de doutorado $\mathrm{O}$ fim do passe e a modernização conservadora no futebol brasileiro (2001-2006). 
rência de jogadores para o exterior foi de aproximadamente 200 atletas. De $1995^{24}$ (depois da sentença Bosman) a 2006, a média de transferências internacionais aumentou para aproximadamente 675 jogadores por ano, algo em torno de um acréscimo de cerca de $240 \%$. Trata-se, portanto, um aumento bem maior na época da Lei Zico e muito mais elevado do que o verificado com a entrada em vigor da Lei Pelé (RODRIGUES, 2007, p. 284; HELAL, 1997, PRONI, 2000; FÁVERO, 2008).

\section{Considerações finais}

$\mathrm{O}$ artigo abordou as transformações pelas quais vem passando o futebol brasileiro nos últimos anos, supostamente provocadas pela Lei Pelé. Apresentou o perfil dos atletas entrevistados, destacando a origem dos atletas, idade dos jogadores, idade da profissionalização dos jogadores, níveis de renda, escolaridade e sindicalização e passagem dos jogadores pelo futebol estrangeiro.

Analisou as concepções dos jogadores brasileiros sobre os impactos da Lei Pelé e do fim do passe no mercado futebolístico nacional. Enfatizou as percepções dos atletas acerca dos efeitos provocados pela nova legislação sobre as transferências internas e externas de jogadores de futebol no Brasil.

As principais constatações deste trabalho, construídas a partir das evidências apresentadas ao longo do texto, foram as seguintes:

- Quanto à idade da profissionalização dos atletas entrevistados, constatou-se que a maioria (47\%) se profissionalizou com 18 anos. A atual legislação admite que a idade mínima para o atleta assinar o primeiro contrato de trabalho como profissional é de 16 anos. A profissionaliza-

24 Em 1995 foram exportados 254 jogadores brasileiros. Em 2006, 851 jogadores deixaram os gramados brasileiros para trabalhar no exterior. 
ção do jogador pelo clube é facultativa entre os 16 e os 18 anos, mas torna-se obrigatória a partir dos 18 anos de idade. As mudanças nos treinamentos, nos esquemáticos e nos ritmos de jogo exigem jogadores mais fortes fisicamente e mais jovens (CARRAVETTA, 2001).

- Em relação ao nível de escolaridade dos jogadores entrevistados, constatou-se que a maioria (64,9\%) tinha como grau de instrução o (ensino médio), algo significativo para o jogador de futebol, visto que estes profissionais não dispõem de tempo para se dedicar aos estudos, e também devido à idéia, muito disseminada na mídia e entre os futebolistas, de que o profissional da bola não necessita de estudos.

- No que diz respeito à renda dos jogadores de futebol no Brasil, as estatísticas mostraram que cerca de $80 \%$ dos atletas profissionais ganham de 1 a 4 salários mínimos. No entanto, a nossa amostra apresentou um nível de renda mais elevado, devido ao fato de que grande parte dos entrevistados era formada por atletas que jogam nos grandes clubes brasileiros, na elite do futebol. Por isso, cerca de 25,8\% responderam que ganha de 7 a 10 salários mínimos.

- Em relação à sindicalização dos jogadores entrevistados, os dados revelam que mais de $50 \%$ dos atletas são filiados aos sindicatos.

- Quanto ao tipo de transferência de jogadores, verificou-se que 40,2\% foram emprestados, 33,3\% estavam sem clube e foram contratados e $26,8 \%$ haviam sido comprados.

- Verificou-se que 33\% dos jogadores já passaram pelo futebol estrangeiro, o que mostra que é elevado o percentual de atletas que já atuaram em outro país, o que evidencia que o futebol é, de fato, um mercado de trabalho globalizado. O processo de globalização tem facilitado as transferências internacionais de jogadores de futebol, abrindo novos mercados para jogadores estrangeiros. Os clubes de futebol funcionam, efetivamente, como verdadeiras empresas transnacionais que consoli- 
dam o comércio internacional de atletas (ROBERTSON; GIULIANOTTI, 2006, p. 13-18).

- A respeito da mobilidade (inter-clubes) dos jogadores de futebol, percebeu-se que o fim do passe criou novas condições para as transferências internas de jogadores brasileiros (mobilidade inter-clubes e inter-regional). Para 64,9\% (63) dos jogadores entrevistados, o fim do passe facilitou muito as transferências internas de jogadores no futebol brasileiro. Trata-se de um percentual elevado, mais que o dobro do percentual de atletas que defendem que o fim do passe facilitou pouco as transferências internas de jogadores (30,9\%) no Brasil.

- Em relação às transferências internacionais de jogadores depois do fim do passe, constatou-se que houve um crescimento. A análise mostrou que as razões desse crescimento devem-se ao fato de que a Lei Pelé facilitou as transferências ao decretar o fim do passe e estabelecer a liberdade de trabalho (opinião de 62,9\% dos jogadores). No entanto, 32\% dos atletas responderam que nada mudou nas transferências internacionais de jogadores no Brasil com o fim do passe, pois o Brasil sempre foi um país exportador de jogadores. Os fatores que impulsionam a migração de jogadores são diversos, transcendem a dimensão legal e envolvem aspectos econômicos, políticos, administrativos, culturais, entre outros.

\section{The end of the passe and the transfer of Brazilian players in an era of globalization}

\section{Abstract}

The article discusses the recent changes in the Brazilian sports legislation and its impact on the labor market. It analyzes the influence of the end of the passe in (internal and external) transfers of football players in Brazil. This is an empirical investigation of the end of the passe and the export of Brazilian players. It 
makes use of quantitative and qualitative research techniques (questionnaires and interviews). The author applied 97 questionnaires to athletes from 12 clubs of the Brazilian football championship series A, B and C. The research indicates that the end of the passe has created new conditions for internal and external transfers of Brazilian players. There was a significant increase in the number of international transfers of players after the end of the passe, expanding the export of Brazilian athletes. In addition to the globalization, the reasons for this increase are due to the fact that the Pelé Law (No. 9615/98) has facilitated the transfers with the end of the passe, allowing more freedom to work and more flexible contracts.

Keywords: Football. Globalization. Players' Transfers. End of the passe. Export.

\section{Referências}

A vez dos empresários. Jornal do Brasil, Rio de Janeiro, 15 set. 1996. Caderno de Esportes, 3.

AFIF, A. Exportação de jogadores brasileiros (2005/2006). Disponível em: www. cidadedofutebol.com.br. Acessado em: 30/08/2006.

AIDAR, A. C. K.; LEONCINI, M. P.; OLIVERIA, J. J. de. (Orgs.). A nova gestão do futebol. Rio de Janeiro: Editora da FGV, 2000.

ALCÂNTARA, H. A magia do futebol. Estudos avançados, São Paulo, v. 20, n. 57, 2006.

Disponível em: <http://www.scielo.br/scielo.php?script=sci_arttext\&pid=S010340142006000200021\&lng=en\&nrm=iso>. Acessado em 12 dez. 2006.

BOUDENS, E. Relações de trabalho no futebol brasileiro II: valor, critérios e condições para o pagamento do passe segundo a resolução/indesp n. 1/96. Estudo, consultoria legislativa. Brasília: Câmara dos Deputados, fevereiro 2002.

. Relações de trabalho no futebol brasileiro III: considerações acerca do $\overline{\text { projeto }}$ de Lei no 2.437, de 1996. Estudo, consultoria legislativa. Brasília: Câmara dos Deputados, fevereiro 2002.

BOURDIEU, P. Program for a Sociology of Sport. Sociology of Sport Journal. n. 2, 1988.

BRASIL. Lei 6816/80. Diário Oficial da União, 19 ago., 1980.

. Congresso Nacional. Lei no 9.981. Brasília, 2000.

. Congresso Nacional. Lei no 9.615. Brasília, 1998. 
BRASIL. Congresso Nacional. Lei no 8.672. Brasília, 1993.

. Congresso Nacional. Constituição Federal, Brasília, 1988.

CAMPBELL, A.; SLOANE, J. P. The Implications of the Bosmann Case for Professional Football. Discussion Paper, Department of Economics, University of Aberdeen, 1997.

CARRAVETTA, É. S. Modernização da Gestão no Futebol Brasileiro: perspectivas para a qualificação do rendimento competitivo. Porto Alegre: Editora AGE, 2006.

. S. O jogador de futebol: técnicas, treinamento e rendimento. Porto Alegre: Mercado Aberto, 2001.

CARTOLAS pressionam CBF. O Globo, Rio de Janeiro, 15 set., 1996. Esportes, p. 7.

CARVALHO, C. A.; GONÇALVES, J. C. A mercantilização do futebol brasileiro: instrumentos, avanços e resistências. Cadernos Ebape, v. IV, n. 2, jun. 2006. Disponível em: http://www.ebape.fgv.br/cadernosebape/asp/dsp_texto_completo. asp?cd_pi=418721. Acessado em 14 jan. 2008.

CRISE no futebol. Folha de São Paulo, São Paulo, 19 set., 1996. Esportes, p. 4.

DA MATTA, R. Antropologia do óbvio: notas em torno do significado social do futebol brasileiro. Revista USP, São Paulo, n. 22, jun./jul./ago., 1994.

DA MATTA, R. et alli. Universo do futebol: esporte e sociedade no Brasil. Rio de Janeiro: Pinakotheke, 1982.

DAMO, A. S. Do dom à profissão: uma etnografia do futebol de espetáculo a partir da formação de jogadores no Brasil e na França. Tese (Doutorado em Antropologia Social) - Programa de Pós-Graduação em Antropologia Social da Universidade Federal do Rio Grande do Sul, Porto Alegre, 2005.

DESEMPREGO no futebol. Zero Hora, Porto Alegre, 18 jun., 2003. Caderno de Esportes, p. 5.

D'OTTAVIANO, R. de O. Fim do passe de jogador: clube deve prestar atenção em outras fontes de receita. Revista Consultor Jurídico, 23 de abril 2001.

ERICSON, T. The Bosman case: effects of the abolition of the transfer fee. Journal of Sports Economics, v. 1, n. 3, august 2000.

FÁVERO, Paulo. O efeito da Lei Bosman no futebol: mudanças que o fim do passe causou na realidade dos jogadores de futebol nas últimas décadas. Antropologia e Sociologia. Disponível em: http://cidadedofutebol.uol.com.br/universidade/ web/site/index_area_estudossociais.asp?arq=artigo.asp\&id_cont $=1553$. Acessado em 29 jun. 2008. 
FGF. Federação Gaúcha de Futebol. Revista Oficial da Federação Gaúcha de Futebol. Porto Alegre: Adventus, 2000.

FERNANDES, L. F. F. A gestão dos clubes de futebol como clube empresa: estratégia de negócio. Dissertação de Mestrado. Programa de Pós-Graduação em Administração da Universidade Federal do Rio Grande do Sul. Porto Alegre: UFRGS, 2000.

FOOTBALL. Le Monde, Paris, 13 dez., 2001. Sports, p. 4.

FUTEBOL do interior. Zero Hora, Porto Alegre, 05 jun., 2003. Caderno de Esportes, p. 2.

GIDDENS, A. Sociologia. 4. ed. Lisboa: Fundação Calouste Gulbenkian, 2004.

. As Conseqüências da Modernidade. São Paulo: UNESP, 1991.

GOOOL - Revista de Todos os Esportes. Porto Alegre, n. 96, 2003.

GURGEL, A. Futebol S/A: A Economia em Campo. São Paulo: Saraiva, 2006.

HELAL, R. Passes e impasses. Petrópolis: Vozes, 1997.

JORNAL GRANDES MOMENTOS DO SPORT. Recife, mai., 1995, p. 4.

LEI Pelé e o mercado do futebol. Folha de São Paulo, São Paulo, 12 ago., 1996. Esportes, p. 6.

LEONCINI, M. P.; SILVA, M. T. da. Entendendo o futebol como negócio: um estudo exploratório. Gestão e produção, v. 12, n. 1, jan./abr. 2005, p. 11-23.

MACIEL, M. R. O contrato de trabalho do jogador de futebol: leis versus realidade. Faculdade de Direito. Centro Universitário Ritter dos Reis. Canoas, 2003. (Trabalho de conclusão de curso).

MAGEE, J.; SUGDEN, J. The world at their feet: Professional football and international labor migration. Journal of Sport \& Social Issues, v. 26, n. 4, november 2002, p. 421-437.

MARQUES, Renato. Bons na bola. E na escola? Na Copa, já chegamos às oitavas. Mas e o estudo de nossos atletas? Disponível em: http://www.universia.com.br/ materia/materia.jsp?id=11472. Acessado em 26 jun. 2006.

MELO FILHO, Á. Nova legislação do desporto (Comentários e atualização) Leis no s. 9. 615/98 e 9.981/00 e MP 2.141/01). Fortaleza: ABC, 2001.

. Futebol profissional: utopias e realidades da nova legislação. Revista Brasileira de Direito Desportivo, v. 4, 2004.

2000, p. 117-118. 
NAPIER, R. D. Manual do Direito Desportivo e Aspectos Previdenciários. São Paulo: IOB, 2003.

NOVO mercado do futebol. Lance, Rio de Janeiro, 17 abr., 2004. Futebol, p. 6.

O fim do passe no futebol brasileiro. Folha de São Paulo, São Paulo, 18 ago., 1996. Esportes, p. 2.

OLIVIER, D. O drama social do mundo da bola. Zero Hora, Porto Alegre, 21 out. 2001, Esportes, p. 56.

PERRY, V. Código Brasileiro Disciplinar de Futebol. 2. ed. Rio de Janeiro: Editora Lúmen Júris, 2000.

PRONI, M. A metamorfose do futebol. Campinas: Editora Unicamp, 2000.

PLACAR. São Paulo: Editora Abril, n. 1142, ago., 1998.

. São Paulo: Editora Abril, n. 1179, ago., 2001.

. São Paulo: Editora Abril, n. 1192, p. 41, 14 ago., 2001.

. São Paulo: Editora Abril, n. 1255, fev., 2003.

. São Paulo: Editora Abril, n. 1256, mar., 2003.

. São Paulo: Editora Abril, n. 1267, fev., 2004.

. São Paulo: Editora Abril, n. 1268, mar., 2004.

. São Paulo: Editora Abril, n. 1269, abr., 2004.

. São Paulo: Editora Abril, n. 1274, p. 32, set., 2004.

. São Paulo: Editora Abril, n. 1300, p. 55, nov., 2006.

REVISTA A+. Rio de Janeiro, n. 3, 2005.

RIBEIRO, C. H. Mais que pendura as chuteiras: o futebol que insiste no social. Rio de Janeiro: Nipress, 2005.

ROBERTSON, R. \& GIULIANOTTI, R. Fútbol, globalización y glocalización. Revista Internacional de Sociologia. Vol. LXIV, no 45, septiembre-deciembre, 9-35, 2006.

RODRIGUES FILHO, M. O Negro no futebol brasileiro. 4. ed. Rio de Janeiro: Mauad, 2003.

RODRIGUES, F. X. F. O fim do passe e a modernização conservadora no futebol brasileiro (2001-2006). 2007. Tese (Doutorado em Sociologia) - PPGS/UFRGS, Porto Alegre, 2007.

. A Lei Pelé e a modernização conservadora no futebol brasileiro: a concepção dos jogadores sobre os impactos do fim do passe no mercado futebolístico. CD-ROM 30 Encontro Anual da ANPOCS. São Paulo: ANPOCS, 2006. 
RODRIGUES, F. X. F. A Sociologia do Trabalho e a Sociologia do Futebol: subsídios para uma análise da flexibilização das relações de trabalho no futebol brasileiro e dos impactos do fim do passe (2001-2002). CD-ROM VII Congreso Argentino de Antropologia Social. Universidad de Córdoba. Villa Giardino, Córdoba, 25 a 28 de mayo 2004.

. Formação do Jogador de Futebol no Sport Club Internacional (19972002). Dissertação (Mestrado em Sociologia) - PPGS/UFRGS, Porto Alegre, 2003. SAÍDA de um jogador por mês deixa Corinthians enfraquecido. Folha de São Paulo, São Paulo, 15 jul., 2003. Esportes, p. 3.

SEITZ, O. A Exportação, o Zico, o Pelé, o Bosman e o Maradona. 2006. www. cidadedofutebol.com.br. Acesso em 29/09/2006.

SOUTO, S. L. Futebol: entre o simbólico e o mercado. In: GARGANTA, Júlio; OLIVEIRA, J.; MURAD, M. (org.). Futebol de muitas cores e sabores. Porto: Universidade do Porto, 2004.

TEORIA \& DEBATE. São Paulo: Editora Fundação Perseu Abramo, n. 48, jun./jul./ ago., 2001.

TOLEDO, L. H.. Lógicas no futebol. São Paulo: Hucitec/Fapesp, 2002.

UEFA football. Le Monde, Paris, 07 dez., 2001. Sports, p. 2.

Recebido: 26/07/2008

Aceite final: 05/02/2009 